\title{
Changes in Carrot Juice Components Due to Fermentation by Selected Lactic Acid Bacteria
}

\author{
Hideki SaKamoto, ${ }^{1,2}$ Masaru Koguchi, ${ }^{2}$ Yukio ISHIGURO ${ }^{2}$ and Tokichi MiYaKaWA ${ }^{1}$ \\ ${ }^{1}$ Department of Fermentation Technology, Faculty of Engineering, Hiroshima University, Higashihiroshima 739, Japan \\ ${ }^{2}$ Research Institute, Kagome Co., Ltd., 17, Nishitomiyama, Nishinasuno-machi, Nasu-gun, Tochigi 329-27, Japan
}

Received May 17, 1996

Lactic acid bacteria were evaluated for suitability in producing a fermented carrot juice. All nine strains of lactic acid bacteria studied grew well in the juice. Sensory evaluation indicated that L. delbrueckii subsp. bulgaricus IAM-1120 and $L$. helveticus JCM-1120 produced the most favorable juice. These strains produced less diacetyl, suggesting that the lack of diacetyl production is an important factor for acceptable fermented juice. Moreover, decreased aldehyde and increased ketone components of fermented carrot juice by these selected strains was observed by gas chromatography/mass spectrometry, and this was suggested to contribute to taste improvement. Although the color of the fermented juice changed in fresh orange color, there was no significant difference in carotenoid composition and their contents.

Keywords: carrot juice, lactic acid fermentation, diacetyl, color, carotenoid

Lactic acid bacteria have a long history in food production, because lactic acid fermentation contributes to improved storage qualities, physical properties and flavor. Recently, the physiological functions of lactic acid bacteria, such as relieving intestinal disorders and having an immunostimulation effect, have attracted public attention (Benno, 1994). Typical examples of foods produced using lactic acid bacteria include processed dairy products (e.g., cheese, yogurt), traditional fermented cereal products (e.g., miso, soy sauce, sake) and processed meat products (e.g., sausage, etc.). It is interesting to note that lactic acid bacteria selected for these foods vary depending on the food materials (Nakano, 1967). For production of lactic acid fermented vegetable products such as sauerkraut and pickles (Daeschel \& Fleming, 1984), halotolerant lactic acid bacteria of the groups Pediococcus or Lactobacillus are used and give the products a specific flavor. However, there were few reports about the lactic acid bacteria suitable for vegetable juice applications.

In this study, lactic acid fermentation was examined using carrots as a substrate. Among vegetables, carrots are the richest in $\beta$-carotene compounds, which are attributed to providing certain health effects (Hart \& Scott, 1995). Because carrots contain only a small amount of organic acids, carrot juice ( $\mathrm{pH} \mathrm{5.6-6.0)} \mathrm{is} \mathrm{a} \mathrm{low} \mathrm{acid} \mathrm{food} \mathrm{and} \mathrm{requires} \mathrm{retort}$ sterilization after canning for storage. However, this sterilization method causes quality deterioration of carrot juice due to severe heat treatment and is an inefficient process for commercial production. In contrast, lactic acid fermentation changes the flavor and results in a more acidic juice which may not require as much heat processing.

To date, malolactic fermentation of carrot juice by the addition of malic acid (Takanami et al., 1991) and traditional Indian lactic acid fermented beverage (kanji) from black carrot (Berry et al., 1989) have been reported. However, organoleptically-preferable lactic acid fermentation and the change in the components of carrot juice due to fermentation have not been adequately studied.

In this study, lactic acid bacteria suitable for the production of carrot juice were selected, and subsequent changes in the carrot juice components due to fermentation were evaluated. More detailed chemical analysis was done on the juice products of specific strains which sensory panelists preferred.

\section{Materials and Methods}

Preparation of carrot juice Carrot juice was prepared by the following process in the Kagome Research Institute pilot plant, Tochigi. Carrots (variety: Kuroda-5-sun) obtained from a local market were washed, blanched in a hot water at $90^{\circ} \mathrm{C}$ for $30 \mathrm{~min}$ and lye-peeled by a roller-type peeling machine. They were crushed into small pieces (average size $2-3 \mathrm{~mm}$ ) using a micrograder Model MR-130 (5 mm screen size, Seiken Co., Ltd., Tokyo) heated to $85^{\circ} \mathrm{C}$ and centrifuged by decanter Model HS-204LS (IHI Co., Ltd., Tokyo) at $3,000 \mathrm{rpm}$ for $10 \mathrm{~min}$. After pasteurization at $105^{\circ} \mathrm{C}$ for $30 \mathrm{~s}$ by a plate-type heat exchanger Model MRS-2 (Hisaka, Works Ltd., Osaka), the juice was concentrated to 36\% Brix by evaporator Model CT-1B (Alfa Laval Co., Ltd., Lund, Sweden) at $60^{\circ} \mathrm{C} 55 \mathrm{cmHg}$ pressure. The mass obtained was packed in a polyethylenefilm bags and stored at $-20^{\circ} \mathrm{C}$ in a freezer.

Before each experiment, concentrated carrot juice was thawed in a cold room $\left(5^{\circ} \mathrm{C}\right)$ and diluted with distilled water to $6.5 \%$ Brix, which corresponded to raw carrot juice. This carrot juice was poured into Erlenmeyer flasks, pasteurized in hot water $\left(95^{\circ} \mathrm{C}, 5 \mathrm{~min}\right)$ and cooled rapidly under running tap water.

Microorganisms and media Lactic acid bacteria used in this study belong to 6 types of genera Lactobacillus, 
Enterococcus faecalis IFO-12694, Leuconostoc mesenteroides IFO-12060, and Streptococcus thermophilus IFO-3535. The six Lactobacillus strains used were L. acidophilus IFO-13951, L. delbrueckii subsp. bulgaricus ( $L$. bulgaricus) IAM-1120, L. casei IAM-1045, L. delbrueckii subsp. delbrueckii ( $L$. delbrueckii) IFO-1085, L. helveticus JCM-1120 and L. plantarum IFO-3070.

MRS broth (Man et al., 1960) was used for lactic acid bacteria growth. BL agar medium (Eiken Chemical Co., Ltd., Tokyo) was used for the determination of the viable cell population as colony forming units (cfu)/ml after cultivation for $48 \mathrm{~h}$ at $30^{\circ} \mathrm{C}$ under anaerobic conditions (BBL Gas Pak, $\mathrm{H}_{2}+\mathrm{CO}_{2}$ anaerobic system, Japan Becton Dickinson Co., Ltd., Tokyo).

Fermentation of carrot juice Lactic acid bacteria were first pre-incubated in MRS medium. The bacteria were inoculated into $100 \mathrm{ml}$ of medium in a $200 \mathrm{ml}$ flask and stationarily incubated at $37^{\circ} \mathrm{C}$ for $20 \mathrm{~h}$ in a water bath. The bacteria showing slower growth were activated by repeating the above procedure. Precultures were prepared by inoculation of MRS culture into $100 \mathrm{ml}$ of reconstituted carrot juice in a $200 \mathrm{ml}$ Erlenmeyer flask at an inoculum ratio of $3 \%(\mathrm{v} /$ v) and by incubation under the same conditions as mentioned above.

For the fermentation test, these precultures were used by inoculation similarly into $200 \mathrm{ml}$ of reconstituted carrot juice in a $500 \mathrm{ml}$ Erlenmeyer flask at an inoculum ratio of $3 \%(\mathrm{v} /$ v) and stationary incubation at $37^{\circ} \mathrm{C}$ for $20 \mathrm{~h}$ in the incubator. After fermentation, all juices, including non-fermented control samples were filled into $200 \mathrm{ml}$ glass bottles and pasteurized at $95^{\circ} \mathrm{C}$ for $5 \mathrm{~min}$. They were stored in a $5^{\circ} \mathrm{C}$ cold room until each analysis.

Chemical analysis Total acidity was determined by titration with $0.1 \mathrm{~N} \mathrm{NaOH}$ and expressed as percent lactic acid. The $\mathrm{pH}$ measurements were made with a $\mathrm{pH}$ meter $\mathrm{F}-12$ (Horiba Ltd., Kyoto) equipped with a glass electrode.

Individual organic acids (citric, acetic, lactic and malic) were determined by HPLC using a Shodex AO-30 system (Showa Denko K.K., Tokyo) and an $8 \phi \times 300 \mathrm{~mm}$ Lonpack $\mathrm{KC}-811$ separating column at $80^{\circ} \mathrm{C}$. Samples were diluted $1: 3$ and a $20 \mu \mathrm{l}$ aliquot was injected after filtration using a membrane filter $(0.45 \mu \mathrm{m})$. The mobile phase was $1 \mathrm{~mm}$ $\mathrm{HClO}_{4}$ at $1.0 \mathrm{ml} / \mathrm{min}$; the eluted acids were passed through a post column reaction system where they were mixed with ST3-P reagent (Showa Denko K.K.) and detected at $430 \mathrm{~nm}$ by a Shodex VD-1 detector.

Carbohydrates (sucrose, glucose and fructose) were determined by HPLC on an LC-3A system (Shimadzu Corp., Kyoto). Samples were diluted $1: 3$ and $20 \mu$ l was injected after filtration using a membrane filter $(0.45 \mu \mathrm{m})$. Injected samples were separated on a $4.6 \phi \times 250 \mathrm{~mm}$ Shodex NH2P-50 column and detected by a refractive index detector ERC-7521. The mobile phase was $75 \%$ acetonitrile solution and the flow rate was $1 \mathrm{ml} / \mathrm{min}$.

The amino acid composition was determined using amino acid analyzer model L-8500 (Hitachi, Ltd., Tokyo). Samples were diluted $1: 5$ with $3 \%(\mathrm{v} / \mathrm{v})$ sulfosalicylic acid solution, and after filtration through a membrane filter $(0.45 \mu \mathrm{m})$, aliquots $(20 \mu 1)$ were injected into the analyzer.
Volatile analysis Volatile components were analyzed by GC-MS using an HP 5972A (Hewlett-Packard Co., Palo Alto, CA, USA) mass spectrometer fitted with an HP 5890 series II GC and an HP Chemstation data system. Carrot juices were centrifuged at $8,000 \mathrm{rpm}$ for $5 \mathrm{~min}$, and the supernatants were diluted 1:10 with distilled water. The mixture of $10 \mathrm{ml}$ diluted sample and $5 \mu \mathrm{l} o$-dichlorobenzene/ benzyl alcohol $(0.012 \%, \mathrm{v} / \mathrm{v})$ solution as an internal standard were put into a $25 \mathrm{ml}$ glass tube. The tube was connected to a Purge \& Trap Concentrator LSC-2000 (Tekmar Co., Cincinati, $\mathrm{OH}, \mathrm{USA}$ ) and held at $60^{\circ} \mathrm{C}$. On purging with helium gas $(40 \mathrm{ml} / \mathrm{min})$ for $60 \mathrm{~min}$, the gases generated were trapped onto a Tenax-TA (GL Science Inc., Tokyo) tube. After $15 \mathrm{~min}$ of helium gas aeration for dehydration, the tube was heated at $200^{\circ} \mathrm{C}$ for 6 min to desorb the volatiles. Then the volatiles were cryofocused at $-100^{\circ} \mathrm{C}$ and directly introduced into the analyzer with a capillary column $\mathbf{J} \&$ W DB-WAX ( $30 \mathrm{~m} \times 0.25 \mathrm{~mm}$ i.d., $d f=0.5 \mu \mathrm{m})$ at $200^{\circ} \mathrm{C}$ for $2 \mathrm{~min}$. The temperature program was isothermal for $1 \mathrm{~min}$ at $40^{\circ} \mathrm{C}$ and was then raised to $190^{\circ} \mathrm{C}$ at $3^{\circ} \mathrm{C} / \mathrm{min}$. The detector temperature was $250^{\circ} \mathrm{C}$. The ionization voltage was $70 \mathrm{eV}$ (EI mode), and the mass range was $m / z$ 35-300. Determination of the diacetyl concentration was done based on standard curves obtained by the same method, using $0.1,0.5,1.0$ and $2.0 \mathrm{ppm}$ diacetyl solutions.

Sensory evaluation Each fermented carrot juice was evaluated by the paired-preference test (Yamaguchi, 1973), using non- fermented carrot juice as a control with 15 trained sensory panelists. Samples were kept in a glass bottle at $20^{\circ} \mathrm{C}$ and were tested under a red lamp to distinguish the difference in color. Panelists were also asked to describe their reasons for selection. Statistical analyses were judged by the two-tailed test.

Color and carotenoid analysis The color of treated carrot juice was measured by a Hunter color difference meter ND- 280 (Nippon Denshoku Ind. Co., Ltd., Tokyo). The absorption spectra of the juice were analyzed using a U-3210 spectrophotometer (Hitachi, Ltd.). The analysis of $\alpha$-, and $\beta$-carotene content and the composition of carotenoids was done by the reversed phase HPLC technique, after extracting the carotenoids from the juice samples. For extraction, $2 \mathrm{~g}$ of each sample were accurately weighed out and mixed with 10 $\mathrm{ml}$ pyrogallol solution $(3 \%, \mathrm{w} / \mathrm{v}), 1 \mathrm{ml} \mathrm{KOH}$ solution $(60 \%$, $\mathrm{v} / \mathrm{v}$ ) and $1.8 \mathrm{~g} \mathrm{KOH}$. Subsequently, the mixture was incubated at $70^{\circ} \mathrm{C}$ for $20 \mathrm{~min}$. After addition of $5 \mathrm{ml} \mathrm{HCl}$ solution $(6 \%, \mathrm{v} / \mathrm{v})$ and $15 \mathrm{ml}$ ethyl acetate/ $n$-hexane $(1: 9, \mathrm{v} / \mathrm{v})$, the mixture was shaken for $10 \mathrm{~min}$. After centrifugation, the supernatant was dried with a stream of nitrogen gas. To the residue, $n$-hexane was added to reach an accurate volume of $10 \mathrm{ml}$; this solution was used for HPLC analysis. HPLC analysis was carried out using a PR-18-5 column (Merck \& Co., Inc., NJ, USA) and solvent (methanol : acetonitrile: dichloromethane: water $=7: 7: 2: 0.16, \mathrm{v} / \mathrm{v})$. Each carotenoid was quantified at $450 \mathrm{~nm}$ wavelength. To determine $\alpha$-, and $\beta$-carotene concentration, calibration curves based on peak area were established using the standard samples (SIGMA Chemical Co., St. Louis, MO., USA), which were prepared as $0.5,1.0,2.0,5.0 \mathrm{mg} \%$ solution in $n$-hexane. 
Table 1. Comparison of acidity, $\mathrm{pH}$, viable cell number and sensory evaluation of carrot juice obtained by fermentation with nine different lactic acid bacteria.

\begin{tabular}{lcccc}
\hline Microorganism & $\begin{array}{c}\text { Acidity } \\
(\%)\end{array}$ & $\mathrm{pH}$ & $\begin{array}{c}\text { Cell number } \\
(\mathrm{cfu} / \mathrm{ml})\end{array}$ & $\begin{array}{c}\text { Sensory } \\
\text { test }^{a)}\end{array}$ \\
\hline L. acidophilus & 0.25 & 4.51 & $2.1 \times 10^{8}$ & $12^{* *}$ \\
L. bulgaricus & 0.41 & 4.09 & $1.3 \times 10^{9}$ & $15^{*}$ \\
L. casei & 0.23 & 4.51 & $5.7 \times 10^{8}$ & $0^{*}$ \\
L. delbrueckii & 0.48 & 3.74 & $5.1 \times 10^{9}$ & $1^{*}$ \\
L. helveticus & 0.42 & 4.03 & $2.3 \times 10^{9}$ & $15^{*}$ \\
L. plantarum & 0.47 & 3.85 & $4.6 \times 10^{9}$ & 7 \\
E. faecalis & 0.29 & 4.34 & $9.1 \times 10^{8}$ & $0^{*}$ \\
Leu. mesenteroides & 0.37 & 4.17 & $3.9 \times 10^{9}$ & 6 \\
S. thermophilus & 0.28 & 4.41 & $9.0 \times 10^{8}$ & $12^{* *}$ \\
\hline
\end{tabular}

a) Number of panelists who preferred fermented to non-fermented carrot juice.

* Significant difference $(p<0.01),{ }^{* *}$ significant difference $(p<0.05)$.

\section{Results and Discussion}

Selection of lactic acid bacteria suitable for fermented carrot juice Strains suitable for the fermentation of carrot juice were selected from 9 lactic acid bacteria based on the values of acidity, $\mathrm{pH}$, viable cell number and sensory evaluation after $20 \mathrm{~h}$ of fermentation (Table 1). All of these strains grew well in the juice. Acid production level was very high in L. delbrueckii IFO-1085 and L. plantarum IFO-3070 (over $0.5 \%, \mathrm{v} / \mathrm{v}$ ). Fermented carrot juice by L. bulgaricus IAM-1120 and $L$. helveticus JCM-1120 were preferred by all of the panelists, and also the juices prepared using L. acidophilus IFO-13951 and Streptococcus thermophilus IFO-3535 were selected as showing significant difference. Based on the majority of descriptions, these fermented juices had a good sour and citrus fruit-like taste. The other strains, especially $L$. casei IAM-1045, L. delbrueckii IFO-1085 and Enterococcus faecalis IFO-12694, produced strong off-flavor taste and were concluded to be unsuitable for carrot juice.

To date, malolactic fermentation of carrot juice with $L$. plantarum has been reported. In this case, the fermentation was done by addition of malic acid and required a long period (4 days) (Takanami et al., 1991). Similarly, lactic acid fermentation of black carrot beverage (mixed with salt water and seasoning) for 10 days was reported (Berry et al., 1989).

In the present study, the following two findings were considered to be interesting. The preferred species ( $L$. bulgaricus, L. helveticus, L. acidophilus and S. thermophilus) for carrot juice fermentation have generally been used for production of yogurt and sour milk; whereas, the unsuitable species ( $L$. delbrueckii, L. casei, L. plantarum and Leu. mesenteroides) had been detected in other fermented vegetable products and cereal products. Secondly, in this study an organoleptically suitable lactic acid-fermented beverage without any additive could be obtained within a short period of time $(20 \mathrm{~h})$.

Specification of flavor components affecting organoleptic differences of fermented carrot juice It was assumed that among flavor components of fermented carrot juice, diacetyl would be most influential in the organoleptic differences. Diacetyl is regarded as a spoilage indicator in tomato juice (Juven \& Weisslowicz, 1981) and orange juice (Sadler et al., 1992); whereas, it is well-known as a positive

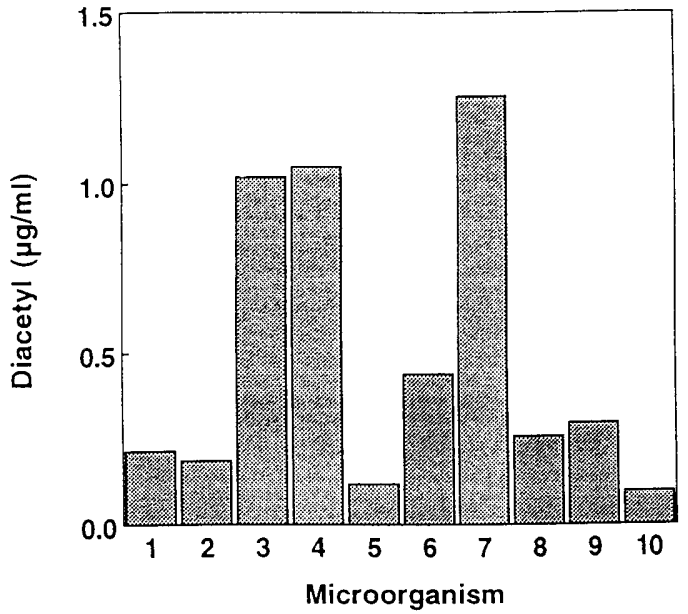

Fig. 1. Comparison of diacetyl fermented by nine lactic acid bacteria and non-fermented carrot juice. (1) L. acidophilus, (2) L. bulgaricus, (3) L. casei, (4) L. delbrueckii, (5) L. helveticus, (6) L. plantarum, (7) E. faecalis, (8) Leu. mesenteroides, (9) $S$. thermophilus, (10) non-fermentation.

flavor component in milk products such as yogurt and cheese (Kaneko et al., 1990). Therefore, the amounts of diacetyl in carrot juice fermented by various lactic acid bacteria were compared by the GC-MS method. Figure 1 shows the formation of diacetyl after fermentation with the 9 strains examined and non-fermented carrot juice. As these figures clearly show, the strains preferred by sensory evaluation ( $L$. helveticus JCM-1120 and L. bulgaricus IAM-1120) formed only a small amount of diacetyl. On the other hand, organoleptically unsuitable strains ( $L$. casei IAM-1045, L. delbrueckii IFO-1085 and Enterococcus faecalis IFO-12694) produced a large amount of diacetyl.

This research showed that an important factor for the selection of an acceptable strain suitable for lactic acid fermentation of carrot juice was the lack of diacetyl production.

The changes in other flavor components were observed by the comparison of GC-MS spectra. The gas chromatograms of carrot juice for non-fermented, fermented with $L$. helveticus JCM-1120 and with L. casei IAM-1045 are shown in Fig. 2, where the peaks showing significant changes are summarized in Table 2. Many of the aldehyde compounds such as peak 3, 3-methyl butanal; peak 5, pentanal; peak 6, hexanal; peak 8, heptanal; peak 10, octanal; peak 14, nonanal; peak 16, decanal, etc., which were commonly known as a flavor components (Maarse \& Visscher, 1989), remarkably decreased, whereas ketone compounds such as peak 9, 2-heptanone, and peak 13, 2-nonanone, were produced by fermentation of L. helveticus JCM-1120. Similar changes were also observed with the juice of $L$. bulgaricus IAM-1120. These ketone compounds exhibited a fruity and sweet aroma on smelling the standard sample. On the other hand, many of these compounds produced by $L$. casei IAM-1045 were not much different from those in non-fermented juice except for a large increase in diacetyl.

In the present study, it has been shown that a decrease in aldehydes and an increase in ketones in carrot juice by selected lactic acid bacteria were characteristic and might 

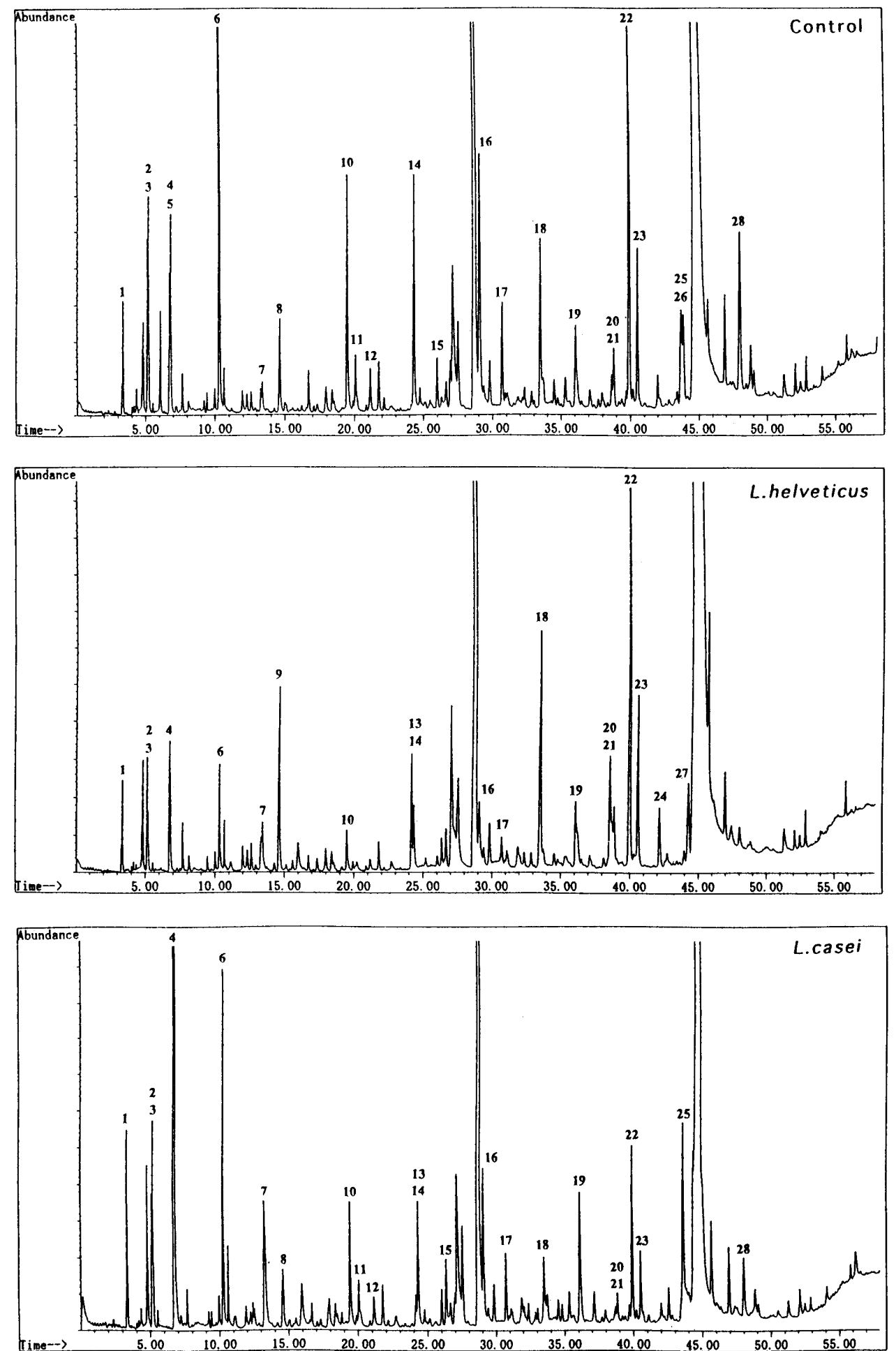

Fig. 2. Gas chromatogram of volatile compounds of non-fermented carrot juice, carrot juice fermented by $L$. helveticus and carrot juice fermented by $L$. casei.

contribute to the improvement of juice qualities. The factors responsible for these changes remain to be solved.

Quantitative characteristics of carrot juice during lactic acid fermentation Figure 3 shows the time course changes in the viable cell number, the titratable concentration of lactic acid and $\mathrm{pH}$, as well as glucose, fructose and sucrose contents during the lactic acid fermentation of carrot juice using the selected strain, $L$. helveticus JCM-1120. This strain grew well in the carrot juice, and the viable cell number increased from $10^{6}$ to $10^{9}$ cells/ml during $20 \mathrm{~h}$ fermentation. In addition, the increase in lactic acid content and $\mathrm{pH}$ lowering caused by the fermentation were significant. This lowering effect of $\mathrm{pH}$ (ca. 4.0) suggests that carrot juice production without retort sterilization after canning is feasible. The sugar content during fermentation decreased with time, and the ratio of glucose, fructose and sucrose did not change significantly. 
Table 2. Odor constituents of non-fermented carrot juice and fermented carrot juices.

\begin{tabular}{|c|c|c|c|c|}
\hline \multirow{2}{*}{$\begin{array}{c}\text { Peak } \\
\text { number }\end{array}$} & \multirow{2}{*}{ Component } & \multicolumn{3}{|c|}{ Relative peak area $(\%)^{*}$} \\
\hline & & a) & b) & c) \\
\hline 1 & 2-Methyl propanal & 1.88 & 0.97 & 3.59 \\
\hline 2 & 2-Methyl butanal & 2.35 & 1.19 & 2.20 \\
\hline 3 & 3-Methyl butanal & 3.29 & 0.70 & 3.86 \\
\hline 4 & Diacetyl & 2.10 & 2.61 & 35.63 \\
\hline 5 & Pentanal & 3.55 & - & - \\
\hline 6 & Hexanal & 13.01 & 1.62 & 8.03 \\
\hline 7 & $n$-Butanal & 0.80 & 1.07 & 5.91 \\
\hline 8 & Heptanal & 2.42 & - & 2.34 \\
\hline 9 & 2-Heptanone & - & 3.31 & - \\
\hline 10 & Octanal & 5.93 & 0.90 & 3.91 \\
\hline 11 & 5Z-Octa-1,5-dien-3-ol & 1.84 & - & 1.26 \\
\hline 12 & $2 E$-Heptenal & 1.35 & - & 1.10 \\
\hline 13 & 2-Nonanone & - & 1.97 & 0.86 \\
\hline 14 & Nonanal & 6.35 & 1.44 & 3.87 \\
\hline 15 & $2 E$-Octenal & 1.38 & - & 2.03 \\
\hline 16 & Decanal & 9.01 & 2.14 & 5.52 \\
\hline 17 & Benzaldehyde & 2.91 & 0.82 & 12.78 \\
\hline 18 & trans-Caryolephyne & 1.33 & 5.52 & 2.69 \\
\hline 19 & 2-Franmethanol & 3.43 & 2.64 & 5.20 \\
\hline 20 & 2-Undecanol & 0.89 & 3.66 & 0.62 \\
\hline 21 & Unknown & 1.66 & 1.53 & 1.02 \\
\hline 22 & Unknown & 11.14 & 10.02 & 5.20 \\
\hline 23 & $\alpha$-Humulene & 4.50 & 3.74 & 2.17 \\
\hline 24 & $2 E, 4 E$-Decadienal & - & 1.46 & - \\
\hline 25 & Hexanoic acid & 3.38 & - & 8.63 \\
\hline 26 & $\begin{array}{l}\text { 6,10-Dimethyl-5E,9E- } \\
\text { undecadien-2-one }\end{array}$ & 3.06 & - & 一 \\
\hline 27 & Unknown & - & 2.42 & - \\
\hline 28 & 1-Dodecanol & 6.74 & - & 2.77 \\
\hline
\end{tabular}

* The relative peak area to that of the internal standard (I.S. peak area $=100$ ) a) Non-fermented carrot juice, b) fermented by $L$. helveticus IAM-1120, c) fermented by $L$. casei IAM-1045.

The comparison of qualitative analyses of carrot juices without fermentation and fermented by $L$. helveticus JCM1120 are shown in Tables 3 and 4 . Concerning the changes in organic acids, the carrots contained a small amount $(0.2 \%)$ of malic acid and lost it during the fermentation process. It is known that lactic acid bacteria, such as L. plantarum, Leu. oenos and Leu. mesenteroides, have malolactic fermentation activity, converting malic acid to lactic acid by decarboxylase reaction (Radler \& Brauhl, 1984). Though the activity of malolactic fermentation in $L$. helveticus has not been reported, the present study suggests its reaction. However, judging from the amount of lactic acid produced (ca. 0.58\%), it was considered that the acid was mainly produced by sugar consumption (ca. $0.54 \%$ ). In terms of the amino acid contents of the juice, only a decrease in aspartic acid content was observed.

Changes in color and structure of carotenoids due to lactic acid fermentation Similarly, changes in color and carotenoids in carrot juice before and after the lactic acid fermentation were examined. The lactic acid fermentation caused a large change in color, leading to a light, favorable color with raised $L, a$ and $b$ values as shown in Table 3. However, this change is almost the same for acidification by acid (data are not shown). In terms of absorption spectra, the spectral pattern was not changed by the fermentation, but the absorbance after the fermentation was higher than before

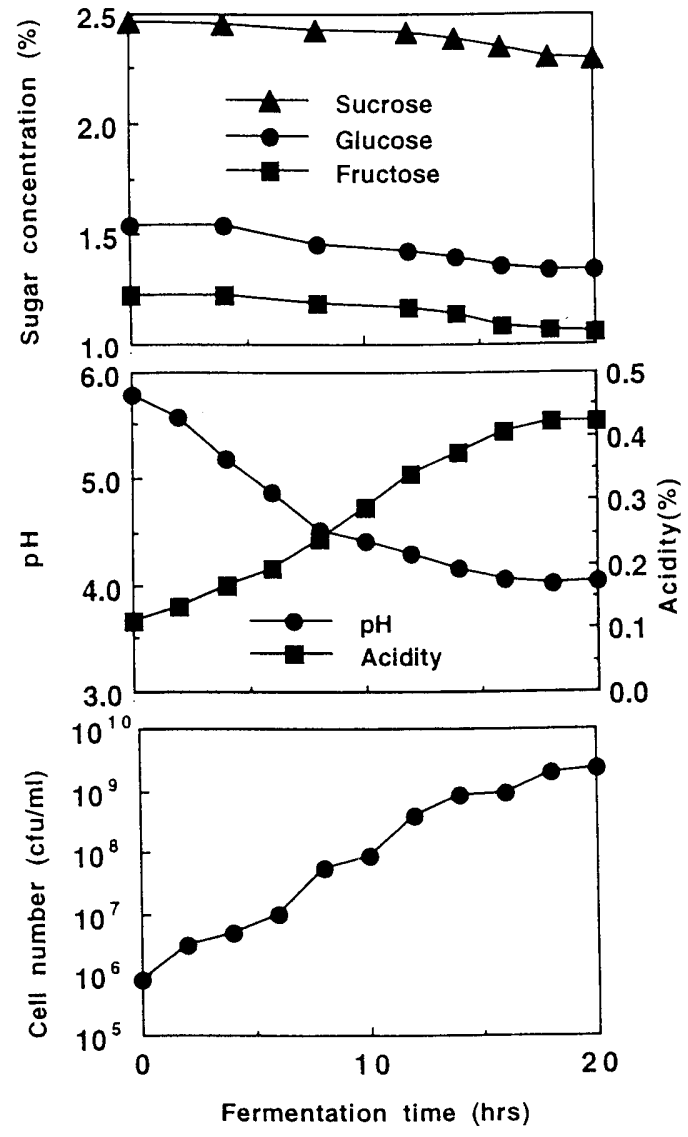

Fig. 3. Growth of $L$. helveticus and changes in $\mathrm{pH}$, acidity and sugar contents in carrot juice during the fermentation.

Table 3. Chemical composition and color parameters in non-fermented and fermented carrot juice ( $L$. helveticus).

\begin{tabular}{lcc}
\hline & Non-fermentation & Fermentation \\
\hline $\mathrm{pH}$ & 5.68 & 4.03 \\
Refractive index (\%) & 6.60 & 6.25 \\
Acidity (\%) & 0.08 & 0.42 \\
Total amino acid (mg\%) & 212 & 197 \\
$L$ value & 27.81 & 29.53 \\
$a$ value & 10.71 & 12.22 \\
$b$ value & 15.57 & 16.58 \\
$a / b$ value & 0.69 & 0.74 \\
Sucrose (\%) & 2.46 & 2.29 \\
Glucose (\%) & 1.54 & 1.34 \\
Fructose (\%) & 1.23 & 1.06 \\
Citric acid (\%) & nd & 0.02 \\
Malic acid (\%) & 0.21 & nd \\
Lactic acid (\%) & nd & 0.58 \\
Acetic acid (\%) & nd & nd \\
$\alpha$-Carotene (mg\%) & 0.83 & 0.81 \\
$\beta$-Carotene (mg\%) & 2.08 & 2.07 \\
\hline
\end{tabular}

nd: Non detected.

(data are not shown). Moreover, the amount of $\alpha$ - and $\beta$-carotene, which are the main carotenoids in carrot juice, was not changed (Table 3) and, as shown in Fig. 4, the carrot juice had a very small amount of xanthophylls, and 5,6-epoxy-carotenoid was hardly detected.

Recently, the color change in carrot juice caused by 
Table 4. Amino acid composition of non-fermented and fermented carrot juice ( $L$. helveticus).

\begin{tabular}{lcc}
\hline Compound & $\begin{array}{r}\text { Non-fermentation } \\
(\mathrm{mg} \%)\end{array}$ & $\begin{array}{c}\text { Fermentation } \\
(\mathrm{mg} \%)\end{array}$ \\
\hline Aspartic acid & 21.4 & 6.1 \\
Threonine & 6.6 & 3.7 \\
Serine & 13.3 & 13.7 \\
Asparagine & 9.3 & 8.7 \\
Glutamic acid & 37.4 & 28.9 \\
Glycine & 2.5 & 5.7 \\
Alanine & 62.9 & 79.2 \\
Valine & 11.6 & 10.9 \\
Methionine & 3.4 & 2.1 \\
Isoleucine & 7.3 & 5.1 \\
Leucine & 4.1 & 2.9 \\
Tyrosine & 2.3 & 2.8 \\
Phenylalanine & 4.7 & 1.8 \\
Lysine & 0.6 & 1.0 \\
Histidine & 1.9 & 0.3 \\
Arginine & 8.0 & 7.8 \\
Proline & 2.5 & 4.9 \\
\hline
\end{tabular}

acidification in the pressing process was reported (Sims et al., 1993). Although this change was considered as an improvement caused by extraction and/or retention of carotenoids the determination of carotenoids contents was not reported. For color change caused by organic acids such as citric acid, there were reports on the color change in Citrus unshiu during storage (Tada, 1987) and in olive berry by lactic acid fermentation (Minguez-Mosquera \& Gandul-Rojas, 1994). These changes were considered to be caused by the conversion of 5,6-epoxy-carotenoid in juice to 5,8-franoxy-carotenoid.

In the present study, it was shown that the color changes in carrot juice under acid conditions could not be attributed to the change in carotenoids. It might be changes in proteins, pectin or other components in the juice that resulted in the spectral changes. The factors responsible for these changes remain to be solved.

\section{Conclusions}

For the development of an acceptable lactic acid-fermented carrot juice, the products using the strains $L$. helveticus JCM-1120 and L. delbrueckii subsp. bulgaricus IAM-1120 were preferred by sensory panelists. These strains hardly produced diacetyl; therefore, it was considered that the lack of diacetyl production activity was the most important factor in the sensory selection. Moreover, a decrease in aldehydes and the occurrence of ketone compounds in fermented carrot juice produced by these selected strains was observed, and it was suggested to contribute to the taste improvement. Although the color of the fermented juice changed to a fresh orange color as a result of lactic acid production, there was no significant difference in the carotenoid composition and their contents.

Acknowledgments We gratefully acknowledge Dr. Michinori Nakamura, Emeritus Professor, Tokyo Univ., Dr. Hiroyasu Fukuba, Emeritus Professor, Ochanomizu Univ., and Dr. Michio Kosaki, Emeritus Professor, Tokyo Univ. of Agriculture, for valuable advice, Shouji Ubukata of the Kagome Research Institute for technical

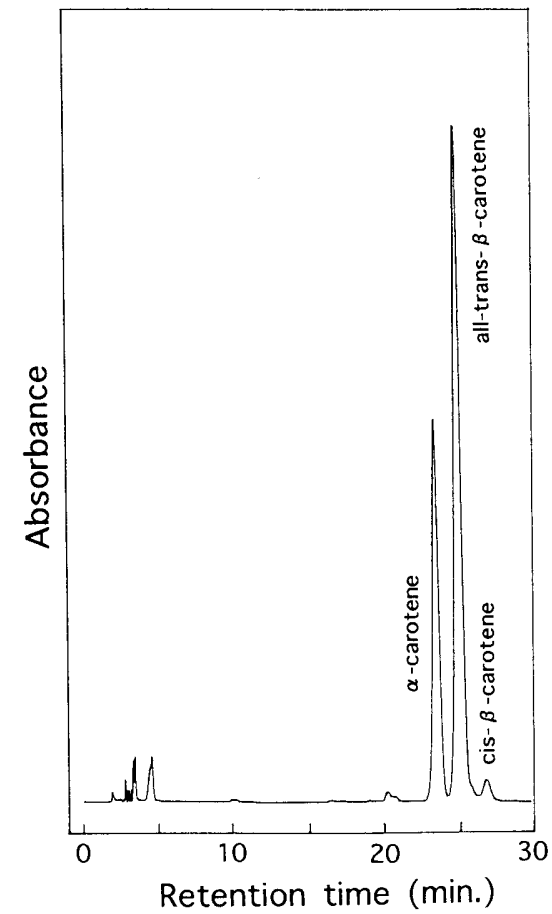

Fig. 4. Elution patterns of carotenoids from carrot juice (L. helveticus)

assistance in GC/MS, and Drs. Karen Lapsley and John Mullin of Agriculture and Agri-Food Canada for assistance with English terminology.

\section{References}

Benno, Y. (1994). Effect of lactic acid bacteria and yogurt on human health. Up-to-date Food Process., 29, 5-7.

Berry, S.K., Joshi, G.J., Saxena, A.K. and Kalra, C.L. (1989). Preparation and evaluation of ready-to-serve black carrot beverage (Kanji). J. Food Sci. Technol, 26, 327-328.

Daeschel, M.A. and Fleming, H.P. (1984). Selection of lactic acid bacteria for use in vegetable fermentation. Food Microbiol., 1, 303313.

Hart, D.J. and Scott, K.J. (1995). Development and evaluation of an HPLC method for the analysis of carotenoids in foods, and the measurement of carotenoid content of vegetables and fruits commonly consumed in the UK. Food Chem., 54, 101-111.

Juven, B.J. and Weisslowicz, H. (1981). Chemical changes in tomato juices caused by lactic acid bacteria. J. Food Sci., 46, 1543-1545.

Kaneko, T., Watanabe, Y. and Suzuki, H. (1990). Enhancement of diacetyl production by a diacetyl-resistant mutant of citrate-positive Lactococcus lactis ssp. lactis 3022 and aerobic conditions of growth. J. Dairy Sci., 73, 291-298.

Maarse, H. and Visscher, C.A. (Eds.) (1989). "Volatile Compounds in Food," TNO-CIVO Food Analysis Institute, Zeist, pp. 211-213.

Man, J.C. de, Rogosa, M. and Sharpe, M.E. (1960). A medium for the cultivation of Lactobacilli. J. Appl. Bact., 23, 130-133.

Minguez-Mosquera, M.I. and Gandul-Rojas, B. (1994). Mechanism and kinetics of carotenoid degradation during the processing of green table olives. J. Agric. Food Chem., 42, 1551-1554.

Nakano, M. (1967). "Fermented Food," Koorin Shoin, Tokyo, pp. $112-115$.

Radler, F. and Brauhl, K. (1984). The metabolism of several carboxylic acids by lactic acid bacteria. Z. Lebensm Unters Forsch., 179, 228231.

Sadler, G.D., Parish, M.E. and Wicker, L. (1992). Microbial, enzymatic, and chemical changes during storage of fresh and processed orange juice. J. Food Sci., 57, 1187-1191.

Sims, C.A., Balaban, M. and Matthews, R.F. (1993). Optimization of 
carrot juice color and cloud stability. J. Food Sci, 58, 1129-1131.

Tada, M. (1987). Conversion of epoxy-carotenoids and color changes of Citrus unshiu juice. Bull. Faculty Agric. Okayama Univ., 69, 3339.

Takanami, S., Kuribayashi, T., Osawa, K. and Yoshida, T. (1991). A new carrot beverage containing fermented lactate; Studies on sour fruit beverage produced by malo-lactic fermentation (Part IV). The Kanzume Ziho (Canners J.), 70, 168-175 (in Japanese).

Yamaguchi, S. (1973). Direct comparisons among samples. In "Sensory Evaluation Handbook" ed. by Research Committee of Sensory Evaluation, Union of Japanese Scientists and Engineers. JUSE Press, Tokyo, pp. 249-252. 